\title{
Krigen 1864 på Kinakysten
}

Af MikKel Leth Jespersen

I 1864 havde hertugdømmernes søfart på Kinakysten nået et anseeligt niveau og dominerede fuldstændig de danske erhvervsinteresser i Fjernøsten. De slesvigske handelsskibe var primært hjemmehørende i Aabenraa, Sønderborg og Flensborg, mens de holstenske skibe næsten alle havde hjemme i Altona. Da krigen brød ud i 1864, viste det sig snart, at hertugdømmernes Kinafarere befandt sig i en usikker position. Preussen, der før krigsudbruddet havde sendt krigskorvetten Gazelle til Fjernøsten på en diplomatisk mission, kunne nu benytte denne mod den danske handel på Kinakysten. Der var ingen danske orlogsskibe i området, som kunne beskytte den danske søfart. Handelsskibene, der endnu alle blev fremført af sejl, havde ikke andet forsvar end et par kanoner, som egentlig kun var beregnet til salut og afskrækkelse af kinesiske pirater. De kunne derfor intet stille op mod et moderne dampdrevet krigsskib. Selvom Gazelle kun opbragte fire fartøjer i alt, og selve opbringelserne var forholdsvis udramatiske, spredte dens aktiviteter utryghed om bord på de andre danske skibe i området. Samtidig blev det diplomatiske forløb omkring dem langt og indviklet. Tabet af Slesvig og Holsten senere samme år betød et alvorligt knæk for tidens danske søfart på Kinakysten.

\section{Indledning}

Mens den hjemlige del af 1864-krigen er udforsket, analyseret og formidlet på alle ledder og kanter, er udløberen på Kinakysten - bortset fra et par enkelte omtaler - ikke behandlet siden krigens umiddelbare eftertid. En skildring findes i viceadmiral Steen Billes (1797-1883) rejseberetning Min rejse til China i 1864, der udkom i København i 1865. Bille rejste som dansk diplomat til Kina for at udveksle ratifikationerne af den dansk-kinesiske venskabs- og handelsaftale (Tientsienaftalen) indgået den 13. juli 1863. Snart blev han ikke blot tilskuer til opbringelserne af de danske skibe, men også deltager i det politiske efterspil. En fordel ved at anvende rejseberetningen som kilde er, at den kan suppleres og sammenholdes med de samtidige dokumenter fra Billes rejse samt materiale fra det danske konsulat i Shanghai, der i dag er placeret på Rigsarkivet. ${ }^{1}$ En anden skildring findes i avisen Dannevirke, som i 1870 bragte en længere artikel: »Preussisk fremgangsmåde imod den i Sønderborg hjemmehørende Skonnert 
»Falk««. Artiklen var et led i den dagsaktuelle debat mellem danske og tyske i Sønderjylland, hvor Dannevirke var de danske sønderjyders talerør på Haderslevkanten. Det kildemæssige arbejde bag skildringen er efter alt at dømme forholdsvis solidt, men der er tale om et politisk indlæg med det eksplicitte formål at belyse, hvor urimeligt preusserne havde behandlet en værgeløs dansk skibsfører. ${ }^{2}$ En arkivkasse i Sønderborg Skipperlaugs arkiv på Sønderborg Slot indeholder en stor samling dokumenter om sagen. ${ }^{3}$

Når der ses bort fra korte omtaler, er begivenhederne i 1864 på Kinakysten på mærkværdig vis gået i glemmebogen i dansk historieskrivning. Vender man blikket mod den engelsksprogede litteratur om Kinas forhold til Vesten i 1800-tallet, omtales Gazelles opbringelser i 1864, fordi de blev et diplomatisk problem for Preussen og på længere sigt var med til at forme tidens kinesiske udenrigspolitik. Forløbet er endnu ikke behandlet i sin helhed, men det skal der nu rådes bod på - her i 150-året efter krigen udspillede sig.

\section{Krigen 1864}

Den første omtale af, at krigen i 1864 kunne få betydning for Kinafarten, findes hos den garvede Aabenraa-kaptajn Jes Peter Boysen fra Dyrhave på Løjt Land. Sammen med Sønderborgstorrederen Christian Karberg og kaptajn Christian Hohlmann ejede han skibet Java, som sejlede i kinesiske farvande under kommando af sidstnævnte. ${ }^{4}$ Den 7. januar 1864 skrev Boysen til Hohlmann, at en krig kunne være under optræk, og at det kunne føre til opbringelser af danske skibe i Kina.

her hos os ser det for Øieblikket ikke godt ud, idet vores Kong Christian [retteligt Frederik] den Syvende døede meget pludseligt, og de tyske Forbundstropper allerede have besat Holsten og truer Danmark med Krig, og dersom det skulde komme til Udbrud, vil det vel blive et Spørgsmaal om det danske Flag i China ikke ville blive opbragt af de preussiske Orlogs-Skibe dersteds, thi Danmark have jo ingen derude [til] at beskytte vores Flag, dog kan ieg ingen Forholdsregler give dem i dette Tilfælde, men de maa selv handle med bedste Overlæg, og eftersom hvad Hr. [Christian] Karberg desangaaende maatte raade Dem .....$^{5}$

Boysen rodede, som det ses, lidt rundt i kongenavnene, men hans brev giver et fint indblik i, hvad der var under opsejling. Den 15. 
november 1863 døde Frederik VII, og tre dage senere skrev Christian IX under på Novemberforfatningen. Den var en gennemførelse af den danske Ejderpolitik, der under ingen omstændigheder kunne accepteres fra tysk side. Tropper fra Det Tyske Forbund rykkede over grænsen til Holsten den 23. december. Den 16. januar fulgte et ultimatum: Hvis Novemberforfatningen ikke blev trukket tilbage, ville krigen være en realitet. Forfatningen blev ikke trukket tilbage, og den 2 . februar 1864 fandt krigens første slag sted. ${ }^{6}$ Skibet Java blev aldrig opbragt, men Boysens analyse af de danske skibes situation i Kina skulle vise sig at have meget for sig. Om Java vides det, at Christian Karbergs søn, Peter Karberg, tilbageholdt skibet den 20. juni i Shanghai på grund af Gazelles opbringelser i løbet af sommeren. ${ }^{7}$ Senere hen forklarede Hohlmann det forhold, at Java kun havde haft et forholdsvis lavt antal fragter, med, at han »havde havt nogen frygt for Opbringelse af den preussiske Gazelle«. Det fortæller Boysen i et brev af den 23. august $1864 .{ }^{8}$ En usikker stemning spredte sig således om bord på de slesvigske og de holstenske skibe, efterhånden som rygtet om Gazelles fremfærd spredte sig.

Den danske reder, hvis forretning blev mest berørt af Gazelles aktiviteter på den kinesiske kyst, var Christian Karberg (1804-1896) i Sønderborg. Han var korresponderende reder for hovedparten af Sønderborgs store langfartssejlere i 1860'erne, mens hans halvfætter Peter Karberg (1805-1882) stod for resten. Christian Karberg var en meget dansksindet og driftig herre, der stod i spidsen for byens dansksindede under Treårskrigen, og som var involveret i mange dele af det sønderborgske erhvervsliv. ${ }^{9}$ Ikke meget er skrevet om ham, men i en nekrolog over Christian Karberg i Dybbøl-Posten kan man læse, hvordan han blev husket, da sejlskibstiden var en saga blot:

»Den for vor $\varnothing$ gyldne Sejlskibstid, da der var aabnet nye Handelsaarer i Vestamerika og Østasien, forstod den driftige Afdøde at benytte baade til eget og Medborgeres Tarv. Alle Verdenshave pløiede dengang et ikke ringe Antal større Skibe, til hvilke Kjølen blev lagt i Sønderborg, hvor ogsaa Besætningerne hørte hjemme, og hvis Hovedrheder den Hedengangne var. Nu har den Oversøiske Dampskibsfragtfart udtørret denne væsentlige Erhvervskilde. [...] Sit danske Sindelag fornægtede han aldrig, og ved Valgurnen var han en sikker mand. «10

- Et levende billede af den rolle Christian Karberg spillede i Sønderborgs langfartssejlads i sejlskibstiden. Desuden kunne man få den 


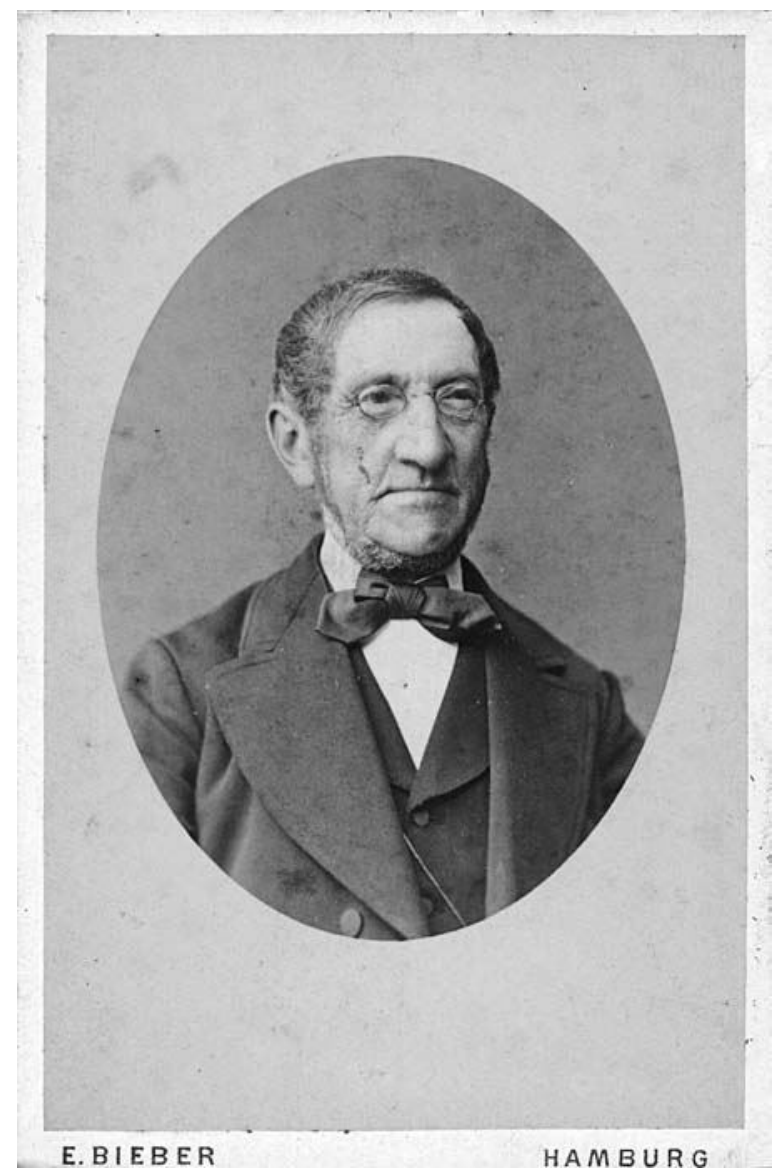

I 1860'erne var matadoren Christian Karberg (1804-1896) Sønderborgs største reder. Familien Karberg havde lenge spillet en central rolle i byens søfart, og nu sad Christian og halvfatteren Peter Karberg som korresponderende redere for alle Sønderborgs Kinafarere. I 1864 havde Peter Karberg byens største skib Virginie på hele 354 1/2 kmcl. Christian Karberg var til gengald hovedreder for ikke mindre end 11 større sejlskibe. Han havde været gift med nu afdøde Nicolina Johanne Magarethe Petersen (1814-1851), som var mor til hans seks børn, hooraf kun tre endnu levede i 1864 blandt andre sønnen Peter, der nu opholdt sig $i$ Shanghai og var involveret $i$ faderens rederi. Foto: Privat.

idé, at det var på grund af skibsrederens danske sindelag, at det netop var hans skibe, der blev opbragt af Gazelle i 1864. Dette kan dog afvises, for som det vil fremgå, var det efter alt at dømme tilfældighedernes spil, hvilke slesvigske og holstenske skibe der blev opbragt. 


\section{Opbringelsen af Falk}

Christian Karbergs skonnertbrig Falk var det danske skib, som Gazelles tilstedeværelse på Kinakysten fik størst konsekvens for. ${ }^{11}$ Det var 66 kommercelæster (kmcl.) stort, bygget i Aabenraa på Heinrich Reimers værft i 1859 og det første af i alt fire skonnertskibe (Falk, Activ, Ida og Chin Chin), som Christian Karberg investerede i ved denne tid. ${ }^{12}$ De blev alle sendt til Kina, da rederen anså skonnertskibene for bedst egnede i disse farvande. Styrken lå dels i deres manøvredygtighed, dels i deres moderate størrelse. De kunne gå ind over barrerne og op ad floderne til de mindre kinesiske pladser. Samtidig var skonnerterne forholdsvis mandskabsbesparende. Falk var klassificeret i det franske Bureau Veritas, hvilket vidner om en vis kvalitet og betød, at det kunne forsikres. Ligesom alle andre Kinafarere var det forsynet med kobberplader under bunden til beskyttelse af skroget mod pæleorm i tropiske vande. Allerede i sommeren 1860 var skibet i fart på Kinakysten. ${ }^{13}$

\begin{tabular}{|c|c|c|c|}
\hline $\begin{array}{l}\text { Falks sejlads } \\
\text { i } 1864\end{array}$ & & & Kaptajn \\
\hline Januar & 1. & Ankommer til Foochow fra Shanghai & Christensen \\
\hline Februar & 18. & Ankommer til Foochow fra Shanghai & Samme \\
\hline \multirow[t]{7}{*}{ April } & 6. & $\begin{array}{l}\text { Afgår fra Foochow mod Chefoo/Tientsien } \\
\text { med Nankeen-klæde, bomuld og } \\
\text { kinesiske varer. }\end{array}$ & Lemmermann \\
\hline & 9. & Set ved »Sharp Peak« Amoy & Samme \\
\hline & 17. & Ankommer til Chefoo & Samme \\
\hline & 22. & Afsejler fra Chefoo mod Tientsien & Samme \\
\hline & 25. & Opbragt af Gazelle i Pe-sche-lee Bugten & Samme \\
\hline & 26. & Ankomst til Taku & Samme \\
\hline & & Otte dages rejse fra Taku til Tientsien & Preussisk officer \\
\hline Maj & 13. & Mandskabet afmønstret & \\
\hline Juni & 5. & $\begin{array}{l}\text { Solgt på auktion i Tientsien til byens } \\
\text { preussiske konsul }\end{array}$ & \\
\hline Juli & 9. & $\begin{array}{l}\text { Afsejler fra Tientsien mod Hongkong med } \\
\text { bønner og bomuld }\end{array}$ & Bobsien \\
\hline August & 23. & $\begin{array}{l}\text { Ankomst til Hongkong, hvor skibet ligger } \\
\text { året ud }\end{array}$ & --- \\
\hline
\end{tabular}


I begyndelsen af 1864 var den hidtidige kaptajn J. Christensen blevet syg og måtte afløses af sin styrmand Hans Christian Peter Lemmermann fra Flensborg. Ud over kaptajnen havde skibet en besætning på ti mand. Den 23. januar havde skibet indgået en fragtaftale på 7.600 $\$$ med Giek Sing, en kinesisk købmand fra Foochow, om tre rejser til det nordlige Kina, og aftalen blev nedfældet i et såkaldt »Charterparty«:

»It is this day mutually agreed between H. Chr. Lemmermann, Master of the danish Schooner Falk of 132 Tons or thereabout, now lying in the River Min Pagoda Anchorage on the one Part and Giek Sing native merchant of Fooschow as Charterer on the other Part. That the said Vessel being light, staunch, strong and in every way fitted for the voyage, shall be placed at the disposal of said Charterer for 3 voyages from here to Chefoo, Tientsin, and Chefoo and back to this port - and further from Foochow to Chefoo or Tientsin or New schwang, but the ship only have to proceed to one of those places and back to Foochow ... The Charterer [is] to have the entire Capacity of the vessel, for loading her with as much legal merchandise as she can safely carry over and above her tackle, apparel, furniture, provision and Cabin ...«.

Inkluderet i aftalen var 100 såkaldte liggedage (søndage ikke medregnet), der skulle bruges til at lade og losse skibet, når det lå i havn det var ikke altid, at en ladning lå klar, og det var ikke altid, at en aftager var parat ved ankomsten, så den slags kunne indimellem tage lang tid. Når de 100 liggedage var opbrugt, skulle Giek Sing betale 30 \$ per dag.

Den 5. april lå Falk klar til at sejle fra Foochow næste dag, og Lemmermann aflagde rapport til Christian Karberg i håb om, at hans første rejse med skibet ville gå heldigt og hurtigt, og at han efter afslutningen af denne fragtaftale ville finde god beskæftigelse for Falk. Endelig havde han læst et brev fra Christian Karberg til Christensen, som må have været flere måneder gammelt. Da det i sin tid var blevet skrevet, havde rederen stadig håbet på, »daß es nicht zu eine Kriege mit Deutschland kommen wird, welches Goth auch verhindern mag «. Gud havde dog ikke forhindret krigen, den var for længst brudt ud, da Lemmermann skrev til Christian Karberg.

Efter kun elleve dage ankom Falk til Chefoo den 17. april. Den 22. gik turen videre mod Tientsien et stykke oppe ad floden Peiho. Ved denne flods munding ligger byen Taku med sine berømte forter til 
beskyttelse af indsejlingen. Det var ud for Taku, at Falk stødte på Gazelle, der havde 320 marinesoldater og 26 kanoner om bord. Få dage forinden var orlogsskibet ankommet fra Japan, og med sig havde det bragt gesandter, der havde udvekslet ratifikationerne af en preussisk-japansk handelsaftale. En af gesandterne var den preussiske konsul i Shanghai, Joseph Maria von Radowitz, der i sine erindringer beskriver, at han blev samlet op af Gazelle i Shanghai omkring den 12. april og sejlet til Taku: »Auf dieser Fahrt traten wir, nachdem die amtlichen Nachrichten über den Ausbruch des Kriegs gegen Dänemark eingelaufen, zum ersten Male mit der »Gazelle« in kriegerischen Aktion, indem wir suchten, unterwegs dänische Kauffahrteischiffe [handelsskibe] abzufangen $\ll .{ }^{14}$ De mødte dog ingen danske skibe på deres fart, og den 18. april kastede Gazelle anker ud for Takuforterne. Gesandterne fortsatte til Peking, mens Gazelle blev liggende i bugten. I den følgende tid opbragte orlogsskibet tre danske skibe; to fra Altona og et fra Sønderborg. Da nyheden om opbringelserne nåede Peking, skulle det vise sig at blive et stort problem for lederen af den preussiske delegation, Guido von Rehfues. Det vender vi tilbage til.

Selve opbringelsen af Falk og det efterfølgende forløb skildrede Lemmermann i et brev af den 15. maj til Christian Karberg. Klokken to om eftermiddagen den 25. april var Falk ankommet til barren ud for Taku, her så kaptajnen en orlogsmand, der lå for anker, men anede ikke uråd. Da Lemmermann gerne ville i havn samme dag, bestræbte han sig på at få fat i en lods så hurtigt som muligt. Et par timer senere fik han øje på en lodsbåd i nærheden af orlogsmanden. Kursen blev sat i denne retning, men nu løsnede orlogsmanden et blindt skud, og det preussiske flag gik til vejrs. Falk, der kun befandt sig mellem halvanden og to engelske mil fra Gazelle, kunne umuligt slippe væk. Der var ikke andet for end at parere ordre, styre i retning af skibet og vise flag. Selve opbringelsen skete på $118^{\circ} 3$ minutter østlig længde og $38^{\circ} 55$ minutter nordlig bredde. Seks sømil ud for Taku. En lods fra Gazelle kom om bord med en officer og tolv bevæbnede marinematroser. Officeren spurgte Lemmermann, om han selv ville hejse det preussiske flag i stedet for det danske, eller om han skulle gøre det. I brevet til Christian Karberg fortæller kaptajnen, at han indvilligede i at gøre det selv og tilføjede straks, at Falk var et slesvigsk fartøj, og at han ville antage preussisk flag og preussiske papirer:

»... der Officier befragte mich ob ich die preusische Flagge statt der 


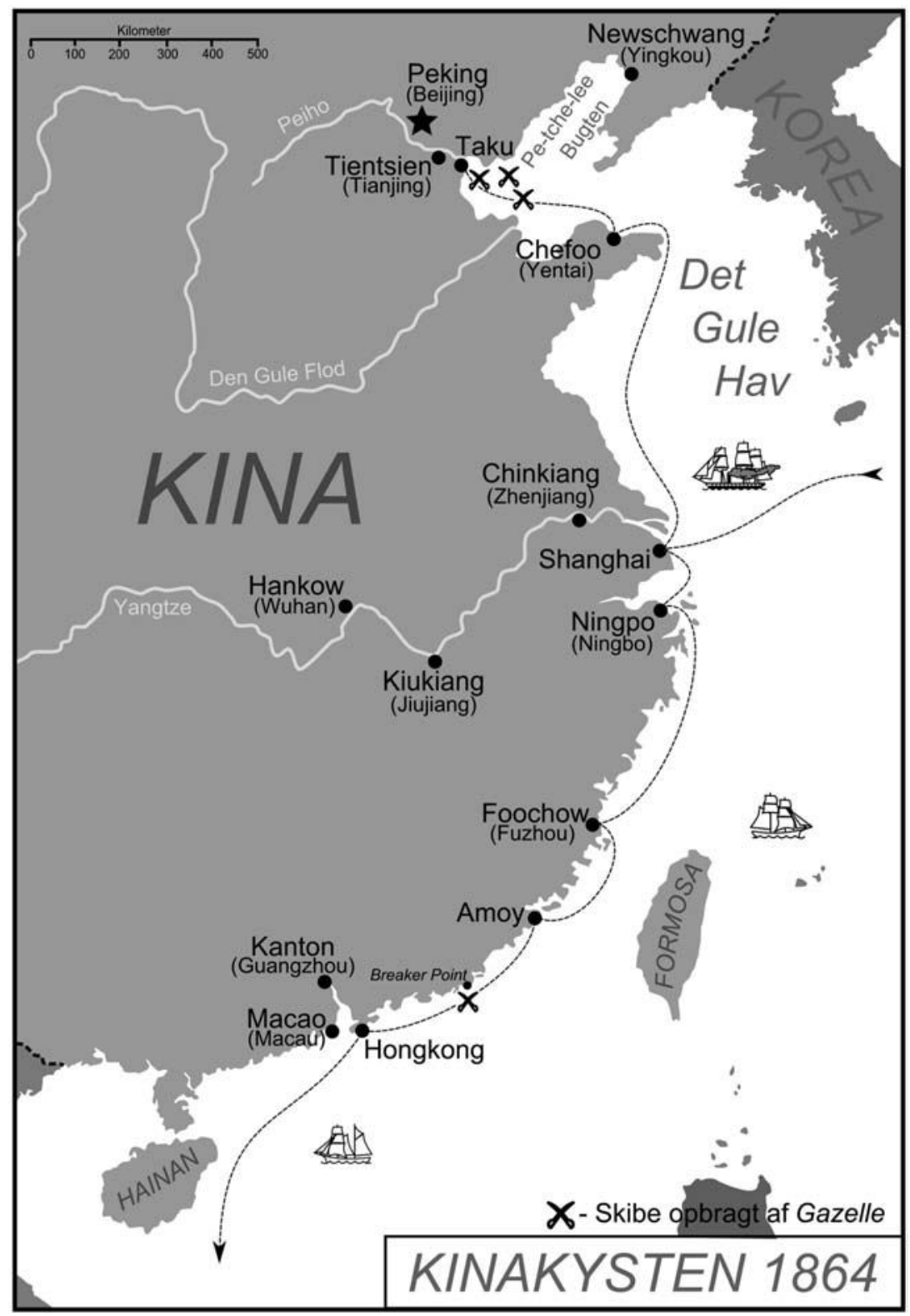

Kortet viser Gazelles sejlads på Kinakysten i 1864 i grove træk med angivelse af de vigtigste havnebyer og de positioner, hvor Gazelle opbragte slesvigske eller holstenske handelsskibe. Kortet er udarbejdet af Thomas Nørregård efter instruktioner fra artiklens forfatter. 
dänische Flagge aufziehen wollte, oder ob er es thuen sollte, worin ich mich willig fügte und sogleich sagte: daß die Falk ein schleswigsche Fahrzeug war und ich die preusische Flagge $u[n d]$ Papiere annehmen wollte ...«

Når nu Lemmermann føjede sig, mente officeren ikke, at skibet ville være i fare. Til spørgsmålet, om kaptajnen ville beholde kommandoen om bord, svarede Lemmermann angiveligt ja. Han blev befalet at ankre op ved siden af Gazelle og at tage sine skibspapirer og charterpartiet med om bord. Det hele blev ham frataget, og Falk blev nu anset for at være Gazelles prise. Samme aften blev forløbet ført til protokols om bord på Falk i overværelse af en bisidder, kaptajnen og flere af korvettens officerer. Næste dag skulle protokollen sendes til den preussiske gesandt i Peking.

Forlader vi kort Lemmermanns brev, så modsiges hans påstand om, at han gik med til selv at udskifte flaget, af Steen Bille i den indledningsvis omtalte rejseberetning. Han fortæller, at Lemmermann ikke fik lov til at sejle videre med Falk, netop fordi han ikke indvilligede i at udskifte skibets flag: »Da Føreren af Skonnerten Falk nægtede at modtage preussiske Papirer og preussisk Flag, blev den bragt ind til Tien-sin «. ${ }^{15}$ Det er uvist, hvilket af de to udsagn der er sandt, men da Falk ikke fik lov til at sejle videre ligesom de øvrige skibe, Gazelle opbragte, kunne det tyde på, at Billes forklaring er rigtig. Måske havde Lemmermann fortrudt, at han nægtede, og fortalte derfor Karberg, at han indvilligede for ikke at komme til at fremstå som den skyldige i opbringelsen.

Tilbage til Lemmermann, som fortæller, at Falk den følgende dag blev sejlet ind i Takus havn af en lods med en officer og seks bevæbnede marinesoldater fra Gazelle om bord. Kommandoen over skibet beholdt han foreløbig selv. Kaptajnens første tanke var at begive sig videre op ad Peiho-floden til Tientsien og indberette hele affæren, men afrejsen blev ham nægtet af den preussiske officer. Samme aften fik han imidlertid ordre om at sejle Falk til Tientsien, men nu protesterede han med den urigtige påstand, at skibet kun var bestemt for Taku. Officeren overtog kommandoen og førte med hjælp fra sine egne folk og Falks besætning skibet til Tientsien. Det tog otte dage. Lemmermann opsøgte den engelske konsul i Tientsien, hr. Gordon, der varetog de danske konsulatsforretninger, men konsulen ville ikke påtage sig sagen mod Preussen - kort tid efter blev han forflyttet. $\mathrm{Nu}$ gik turen til den preussiske konsul Alexander Alisch for at finde ud 


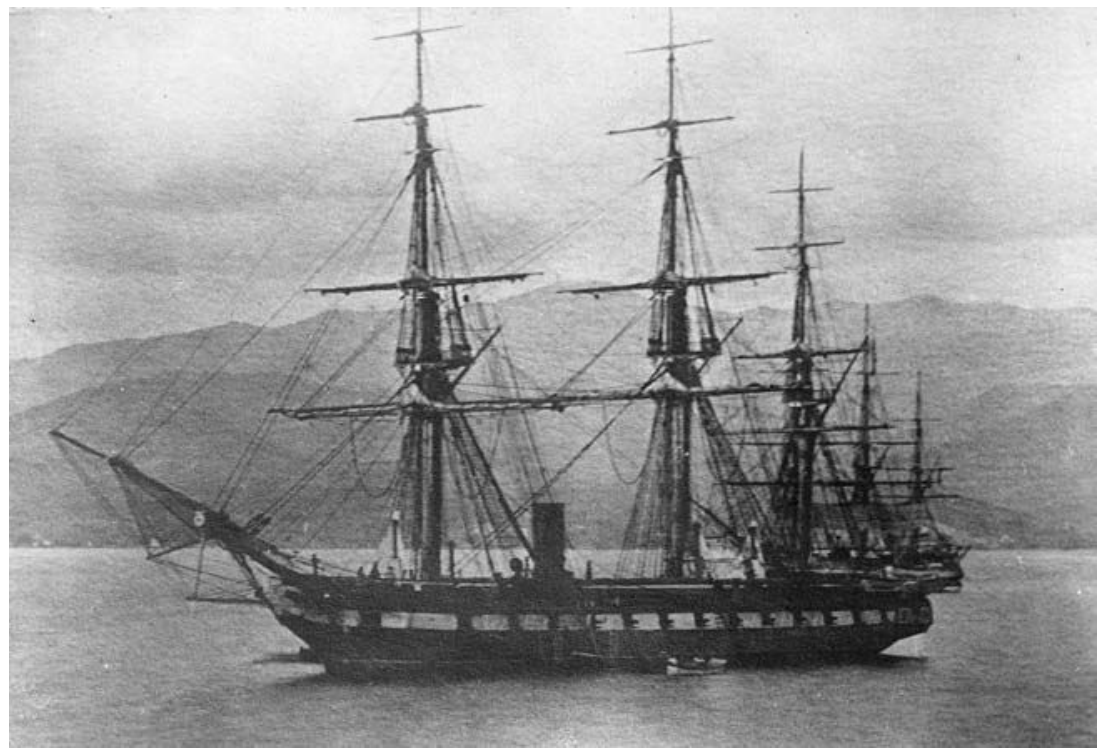

Samtidigt fotografi af den preussiske skruefregat Gazelle, der tilfxldigvis befandt sig $i$ Fjernøsten, da krigen 1864 brød ud. Skibet løb af stablen på det kongelige orlogsværft $i$ Danzig i december 1859 og blev inddraget i flåden i maj 1862. Det var armeret med seks 68 punds kanoner og 2036 punds kanoner. Om bord pa dette togt var 320 marinesoldater. Det var således en smal sag for den tungt armerede Gazelle at opbringe de i grunden forsvarsløse danske handelsskibe. Det er uvist, hvor og hvornår fotografiet er taget, men ud fra landskabet $i$ baggrunden at dømme kan det stamme fra togtet til Fjernøsten $i$ 1864. Foto: Bundesarchiv - Institut für Meereskunde, Bild 134.

af, hvad der skulle ske med Falk. Alisch, der endnu ikke havde hørt fra Peking, vidste intet. Senere blev ladningen frigivet af Alisch og overdraget til dens kinesiske ejermand. Andre kilder beretter, at kineseren blev afkrævet et uretmæssigt beløb for at få udleveret godset. Falk blev aftaklet og alt inventar bragt i land, efter at Lemmermann havde opført det på en liste. Den 13. maj blev mandskabet afmønstret.

Lemmermann fortæller, at Gazelle kort tid efter opbragte endnu to danske skibe, begge fra Holsten: Caroline på 791/2 kmcl. førtes af kaptajn A. Appen og kom fra Blankenese, mens briggen Catharina på $90^{1} / 2$ kmcl. førtes af J.C. Overbeck fra Aabenraa og kom fra Altona. Selve opbringelserne er ikke beskrevet, men begge skibe blev straks løsladt igen, mod at kaptajnerne indvilligede i at tage preussisk flag og preussiske papirer. Hvad Falks skæbne angik, så havde Alisch udtrykt, at skibet hverken ville blive solgt eller udleveret mod kaution, 
men det ville blive $\mathrm{i}$ havnen som prise, indtil krigen var forbi. Lemmermann selv ville afvente postgangen fra Europa og håbe på bedre tidender, ellers ville han drage til Shanghai for at give, hvad han havde af papirer og effekter fra Falk til Christian Karbergs søn, Peter Karberg, der her var ansat i firmaet Oxford og Co. Rejsen til Shanghai blev ikke til noget. Afslutningsvis gentog han ønsket om fred mellem Danmark og Preussen, så priseskibene kunne blive udleveret, og han igen kunne få overdraget Falk, med hvilket han havde haft så lyse udsigter.

\section{Danske kaptajner i Shanghai}

Senest den 17. maj havde nyheden om Gazelles opbringelser nået Shanghai. I et brev dateret denne dag skrev fem kaptajner og redere til byens fungerende danske konsul William Keswick. Kaptajnerne forklarer, at Gazelle har taget adskillige danske skibe og ført dem til Tientsien, og de beder Keswick - som den danske majestæts ambassadør ved hoffet i Peking - tage kontakt til den kinesiske regering med det budskab, »that it is against the international laws of civilized nations; for any belligerent power, to bring prize vessels into neutral ports!« Kaptajnerne ville endvidere anse det for en stor tjeneste, hvis Keswick henvendte sig til den britiske ambassadør i Japan for at få denne til at gøre det samme klart for den japanske regering. Blandt de fem underskrivere står P. Karberg; "på vegne af Falks ejermand «. ${ }^{16}$

Den 12. juni fulgte endnu et initiativ fra kaptajnerne i Shanghai. Kredsen var nu udvidet med fire kaptajner - to danske, hvoraf den ene var Christian Hohlmann (kaptajnen på Java af Sønderborg) og to norske. De ni kaptajner udsendte »Indbydelse til bidrag for de i kampen i Danmark faldnes Efterladte, såvel som for de saarede og deres familier«. Da de var forhindret i aktivt at deltage i kampen for fødelandet, ville de nu opfordre deres landsmænd og andre til at give en skærv til »det lille Danmarks heltemodige Frihedskamp imod 2 af Europas Stormagter «. Af gode grunde var der ikke udsigt til, at venligtsindede magter ville komme Danmark til undsætning, men et bidrag ville hjælpe til at »opretholde vore tapre Krigeres Mod «. Således kunne soldaterne kæmpe for Danmarks frihed, »saalænge der er ånde i dem i den glade Overbevisning ", at deres efterladte ikke ville komme til at lide nød, »naar den Haand er kold, der ellers fodrede dem «. Konsul Keswick havde lovet at sørge for, at de indsamlede penge ville blive sendt hjem snarest muligt. Herefter fulgte en engelsk oversættelse 
af opfordringen og en liste over de personer, der havde bidraget - først og fremmest besætningsmedlemmer på danske og norske skibe.

Nyheden om indsamlinger blandt de danske støtter langs Kinakysten nåede helt til Hankow, langt oppe ad Yangtze-floden. Den 21. juni skrev Chas. Gram - en dansker der arbejdede for toldvæsenet i Hankow - til Keswick i Shanghai, at han havde hørt, at de danske indbyggere i Hongkong samlede ind til støtte for deres lidende landsmænd. Vedlagt brevet var derfor en pakke med et guldur, som han havde taget i den kinesiske kejsers sommerpalads i 1860 (»It contains a Goldwatch from the Emperor of Chinas summerpalace 1860«) - han må have været med de britiske tropper, som dette år indtog Peking, hvorefter de plyndrede og nedbrændte sommerpaladset. Uret var et bidrag til indsamlingen, og Keswick skulle sende brevet og pakken videre til det danske konsulat i Hongkong. Det gjorde Keswick, for den 20. august kvitterede den danske konsul i byen, nordmanden George Helland, for modtagelsen og lovede at sende uret videre til København ved førstkommende sikre lejlighed. ${ }^{17}$ Den danske viceadmiral Steen Bille fortæller, at han i sommeren 1864 i Hankow mødte denne hr. Gram fra København, »som efter flere Eventyr var havnet her «. Han var blandt de toldkontrollører, som briterne havde indsat til at opkræve den told, de skulle have i krigsskadeerstatning af den kinesiske regering efter Den Anden Opiumskrig. ${ }^{18}$

Hen mod slutningen af juni var samme Steen Bille ankommet til Shanghai. I sin rejseberetning fortæller han om sine »Bestræbelser for at slaa lidt koldt Vand i Blodet paa de brave danske Skibs-Kaptajner i Shanghai, som jeg ved min Ankomst der fandt ikke lidt exalterede«. Ifølge Bille bad nogle af dem, der anså deres fartøjer for velsejlende, ham ligefrem om at udstede kaperbreve, så de kunne opbringe preussiske handelsskibe. Det tog angiveligt ikke Bille megen overtalelse at få kaptajnerne til at opgive ideen. Bille havde ingen fuldmagt til at udstede kaperbreve og ønskede på ingen måde at påtage sig ansvaret for et sådant forehavende. Udslagsgivende var dog, at han mindede kaptajnerne om, at de ikke havde noget sted at bringe deres eventuelle priser hen. Sejlede de en prise ind i en kinesisk havn, ville repræsentanterne for de neutrale magter - vel først og fremmest Storbritannien og Frankrig - blive oprørte, hvilket ville skade Danmarks sag og volde regeringen store ubehageligheder: »Dette forstod disse brave mænd meget snart, og de sloge sig da til Taals, men det var sandelig med dybt bevæget Sind, at jeg skildtes fra dem efter disse Samtaler, 

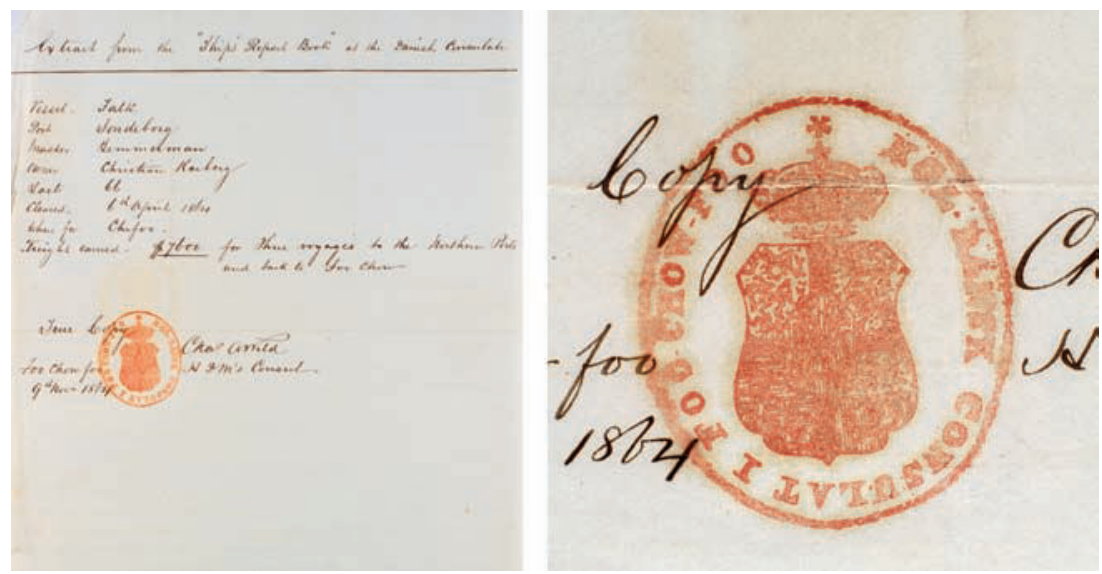

Efter indgåelsen af aftalen om de tre rejser til det nordlige Kina blev den rapporteret til det danske konsulat $i$ Foochow og indført $i$ den såkaldte "Ships Report Book « med alle væsentlige oplysninger om Falk. Under retssagen $i$ Hongkong rekvireredes en kopi af denne indførelse. Det fik man med dette danske konsulatsstempel under. Teksten lyder »KGL. DANSK CONSULAT I FOO-CHOW-FOO«, og brevet er underskrevet af byens danske konsul Charles Wild.

og at jeg fik et levende og kraftigt Beviis paa hvor inderligt alle disse herlige Folk, hvoraf de fleste var fra Slesvig, hængte ved deres haardt betrængte Fædreland. «19

Den stærke nationalfølelse og kampvilje, der prægede Danmark i 1864, var således også til stede hos den af sønderjyder dominerede gruppe danske kaptajner på Kinakysten.

\section{Falk og Chin Chin}

Mens de oprørte danske kaptajner samlede penge ind i Shanghai, lå Falk stadig i Tientsien, fordi den engelske konsul havde afvist at tage hånd om sagen. Ifølge Bille var sagen »bleven behandlet paa en meget skjødesløs og folkeretstridende Maade «. ${ }^{20}$ Den øverste kinesiske myndighed i byen, General-Guvernør mm. Chung-hov, havde vist nok på fornemmelsen, at noget ikke var helt, som det burde, men han havde ikke vist Falk ud af havnen.

Det var formentlig manglen på dansk repræsentation i Tientsien, der gav den preussiske konsul i byen, Alisch, et stort spillerum, som han efter alt at dømme udnyttede på den mest udspekulerede måde. Først lod han Falk udbyde på auktion, men da Chung-hov havde 
ladet byens udenlandske konsuler vide, at der ikke måtte bydes på priseskibet, inden der var afsagt dom i sagen, var der ingen interesse. Det afholdt dog ikke Alisch selv fra at sælge skibet til sig selv! Det skete allerede den 5. juni, men uden at det blev klart for Lemmermann. Salget omtales derfor ikke i hans følgende breve hjem. Den 20. juni havde han »keine erfreudigen Nachrichten [...] doch will ich hoffen, daß bald bessere Nachrichten für den Schleswigschen Schiffe an der Kina Küste antreffen mögen «. ${ }^{21}$

I Tientsien afventede man dagligt to af Christian Karbergs andre skonnerter, nemlig Chin Chin ført af kaptajn Schmidt og Ida ført af kaptajn Jessen. Lemmermann håbede, at de ikke stødte på Gazelle. Selv befandt han sig om bord på den fjerde af Karbergs skonnerter, Activ, der førtes af kaptajn Leworni. Skibet lå for tiden stille i Tientsien, mens kaptajnen ventede på nærmere instruktioner fra Peter Karberg i Shanghai, der for øvrigt ved denne tid tilbageholdt Java på grund af opbringelserne. Det var ikke nogen dårlig idé. Inden længe var Chin Chin nemlig taget af Gazelle ved Breaker Point (22 $56^{\prime}$ N.L. $116^{\circ} 8^{\prime}$ Ø.В.) og ført til Hongkong som prise.

Hvordan denne sag udviklede sig, kan Steen Bille fortælle. Han ankom til Hongkong den 18. juni og så Chin Chin ligge i havnen med dansk flag. Det var kun få dage siden, at Gazelle havde slæbt det ind. Da den danske konsul Georg Helland hørte om Chin Chins skæbne, tog han prompte affære og kontaktede byens britiske guvernør, Sir Hercules Robinson. Guvernøren beordrede straks chefen for Gazelle, at han enten måtte forlade havnen med prisen eller sætte den fri. Chin Chin blev da sat fri, og besætningen kunne atter hejse Dannebrog. Det forlød, at nye ordrer fra Preussen betød, at alle slesvigske og holstenske skibe uden undtagelse skulle anses for neutrale og have lov til at sejle videre under dansk flag. Om det var sandt, tvivlede Bille. Han fortæller videre:

»Denne Sag [om Chin Chin] var saaledes fuldkommen afgjort forinden jeg ankom til China. Jeg følte selvfølgelig, at det var min Pligt, ved Siden af de mig befalede Forretningers Udførelse, at gjøre hvad jeg formaaede for at modvirke den skadelige Indflydelse, som denne fjendtlige Orlogsmands [Gazelles] Nærværelse maatte have paa vor Skibsfart i disse Farvande. Hvad jeg i saa Henseende foretog mig, og hvad Resultat jeg opnaaede, vil blive udviklet i det Følgende. Her skal jeg blot fortælle, at jeg i Samtaler med de herværende Skibscaptainer gjorde mit Bedste for at sætte Mod i dem og til at fortsætte deres Fart uden at ændse Gazellen, som jo dog kun kunde være paa eet Sted ad 
Gangen, og som i sit ringe Kulforraad, forholdsviis til Farvandets Udstrækning, maatte være indskrænket i sin Virksomhed. Jeg fandt dem Alle ved godt Mod. Endeel af dem vare [be]fragtede [i] maanedsviis; for dem var Pengespørgsmaalet ligegyldigt, kun Kjedsomheden ved at ligge ørkesløs var dem til Besvær, - for Andre, som fore paa Fragt reiseviis, var Stillingen vanskeligere, thi Frygten for Opbringelse holdt naturligviis Befragterne tilbage, dog var Tilliden til de danske Skibe saa stor, at ogsaa denne Frygt flere Gange overvandtes, og ved stadig Opmærksomhed paa den preussiske Fregats Bevægelser lykkedes det ogsaa at undgaae den i de allerfleste Tilfælde. Af den store Mængde danske Skibe, som drev Fragtfarten langs Chinas Kyst, opbragte Gazelle i Alt kun 3 Skibe, foruden den ovennævnte Chin-chin, og disse tre bleve alle tagne i Pet-chu-li-Bugten, medens Preusseren laae til Ankers der ud for Taku-Forterne ved Peiho-Flodens Munding. Med Undtagelse af Chin-chin, tog han ingen danske Skibe i aaben Sø. $\ll^{22}$

En af de danske kaptajner, som Bille kunne have mødt på Kinakysten, var J.A. Ohlsen fra Flensborg, der førte skibet Peiho af Altona. Han ankom til Kinakysten, netop som krigen brød ud i begyndelsen af 1864. Skibets hovedreder var C. Brodersen i Altona (der for øvrigt købte flere skibe sammen med Christian Karberg). Medreder var P.J. Petersen i Flensborg, som kaptajnen sendte en lille serie bevarede breve. ${ }^{23}$ I et af brevene, dateret Shanghai den 20. juni, fortæller kaptajnen, at han var usikker på, hvordan det ville gå, når den aftalte månedsfragt udløb. Kineserne ville ikke længere befragte skibe, der sejlede under dansk flag. Han mente dog, at situationen var lige så dårlig for skibe fra Preussen, Hamborg og Bremen, da mange troede, at England snart ville gå ind i krigen på dansk side. Skete det, ville Ohlsen være på den rigtige side. Han håbede dog på en snarlig afslutning med en lykkelig udgang for »unseres Land«, altså Danmark. Afslutningsvis fortalte han om Gazelles opbringelser af Falk, Chin Chin og Caroline. I et senere brev, dateret Chefoo den 20. juli, oplyste Ohlsen, at han trods dårlige tider for fragtfarten var ved at laste skibet for Hongkong, og at han ikke længere bekymrede sig »wegen der Flagge«. Nu var frygten for Gazelle tilsyneladende drevet over.

\section{Steen Billes cirkulære}

Fra Hongkong drog Bille, som nævnt, til Shanghai. Her udstedte han den 1. juli et duplikeret cirkulære til samtlige danske konsulater langs 
Kinakysten. ${ }^{24}$ Det indledtes med, at skibene Catharina, Caroline og Falk var blevet taget af et preussisk orlogsfartøj og nu sejlede som preussiske handelsskibe under preussisk flag. Derpå fulgte en forklaring på, hvorfor preussernes fremgangsmåde overtrådte international ret. Det var den primært på grund af de kinesiske farvandes og havnes neutralitet. Dertil kom, at ingen af opbringelserne var blevet prøvet ved en priseret, og at nationalitetsændringerne ikke var foregået ved en ceremoni. I sit cirkulære instruerede Bille således de danske konsuler om, at de skulle være opmærksomme på de ovennævnte tre fartøjer og lignende tilfælde. Ankom et priseskib til havnen eller til konsulatsdistriktet, skulle konsulerne omgående protestere til de relevante kinesiske myndigheder mod, at fartøjerne ikke blev behandlet som lovlige handelsskibe, og forbeholde ejernes rettigheder mod de preussiske autoriteters ulovligheder. Konsulerne blev pålagt at bruge alle til rådighed stående midler til at bringe sådanne skibe tilbage under dansk flag. Endelig skulle de rapportere til Udenrigsministeriet i København om alle initiativer, de måtte tage i henhold til cirkulæret. ${ }^{25}$

Inden længe gav cirkulæret bonus. Skibet Catharina ankom i samme måned til Foochow, og her tog byens fungerende danske konsul, briten Charles A. Wild, affære. Da skibet atter sejlede ud af havnen den 18. juli, førte det dansk flag. Wild fortæller, at skibet ifølge sine papirer havde hjemhavn i Altona, og at rederen J. Kjær i samme by var dansk undersåt: »it was therefore impossible that the Vessel should be allowed to remain under Foreign Colours", sluttede han sit brev, dateret den 22. juli. ${ }^{26}$ Ifølge Billes rejseberetning foregik flagskiftet »til Besætningens store Glæde $\ll .{ }^{27}$ Wilds støtte til den danske sag betalte sig, han blev i august forfremmet fra fungerende dansk konsul til dansk konsul i Foochow.

Fra Shanghai rejste Bille mod Tientsien om bord på den engelske skruedamper Nansing. Undervejs mødte han Falk ud for Taku-forterne ved indsejlingen til Peiho-floden, der skulle føre Nansing til Tientsien. Alisch havde omdøbt Falk til Bachantin, rigget skibet til igen og givet det ny besætning. Nu var Bachantin på vej mod Hongkong med bønner og bomuld. Kaptajn Lemmermann var fulgt efter om bord på Activ. Den 7. juli mødtes Bille og Lemmermann ved Taku. Under deres møde fik Lemmermann det indtryk, at Bille ikke kunne hjælpe med at få Falk fri, men at han i stedet for anbefalede Lemmermann at opsøge den danske konsul i Hongkong. Bille nævner også mødet med Lemmermann, som han angiveligt fandt »drivende om paa Kaien ... «. ${ }^{28}$ Lemmermann 


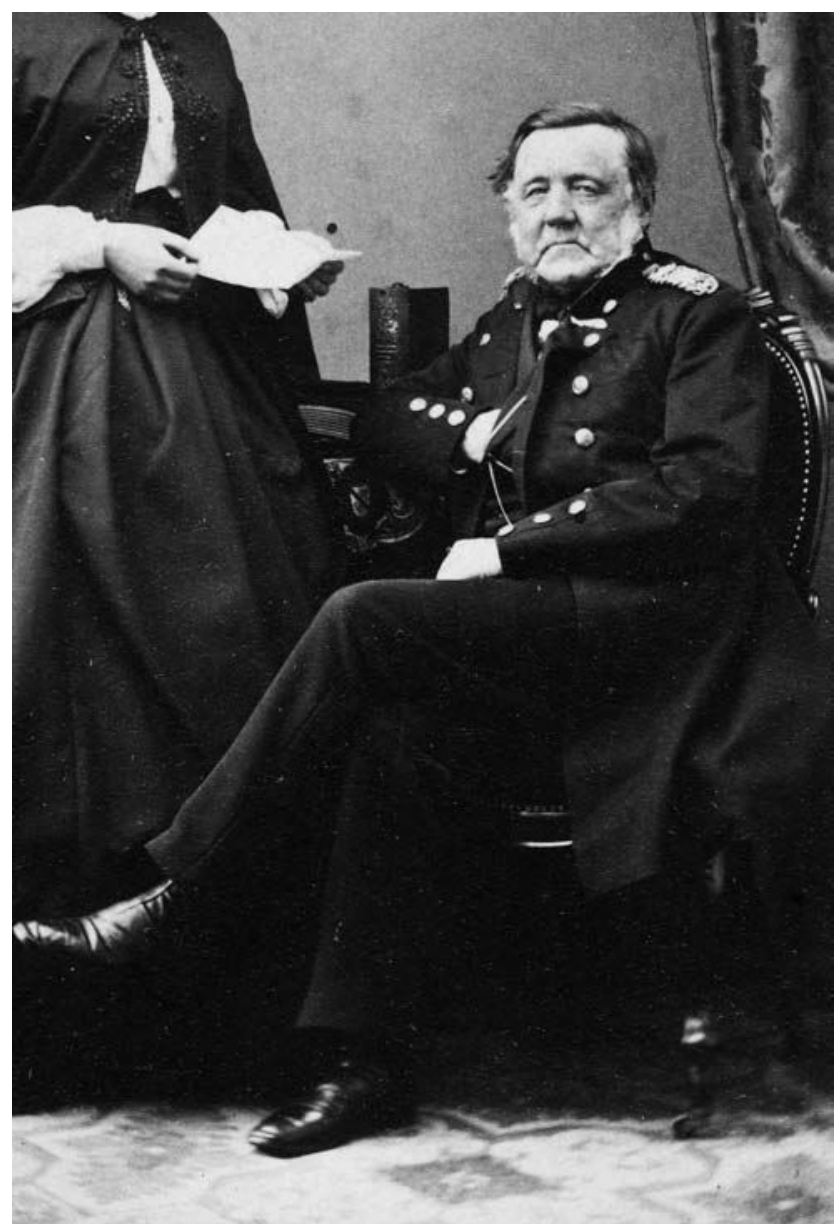

Viceadmiral Steen Andersen Bille (1797-1883) var på hele to diplomatiske rejser til Fjernøsten. Første gang var som chef for orlogsskibet Galathea, der sejlede jorden rundt fra 1845 til 1847. Anden gang var $i$ 1864, hoor han stod for at udveksle ratifikationerne af den dansk-kinesiske handelsaftale, som var blevet indgået året forinden. Foto: Det Kongelige Bibliotek.

fulgte efter Falk til Hongkong, mens Bille fortsatte til Tientsien for at udveksle ratifikationerne og dermed afslutte sin mission.

I Tientsien lå Caroline endnu under preussisk flag. Modsat de tre andre kaptajner, hvis skibe var blevet opbragte, havde kaptajn Appen på Caroline ikke haft noget problem med at skifte til preussisk flag. Efter opbringelsen havde skibet været en tur i Shanghai, hvor kaptaj- 
nen havde meldt sig til den preussiske konsul. Da den danske konsul Keswick havde erfaret, hvordan det forholdt sig med skibet, var det allerede losset og sejlet $\mathrm{i}$ ballast til Tientsien, en by uden dansk konsul, der kunne nedlægge protest. Bille holdt sig indtil videre ude af sagerne, men havde drøftet situationen med Appen. Kaptajnen havde forklaret, at han havde taget det preussiske flag for at kunne sejle frit. Da havde Bille spurgt, om Appen ikke fandt det forkert at sejle under falsk flag, men kaptajnen var helt uforstående over for dette. Han var jo holstener og ville aldrig i livet blive preusser. Da Caroline senere ankom til Hongkong, blev skibet tilbageholdt på den danske konsuls protest, fordi kaptajnen ikke havde afleveret sine papirer til trods for, at skibet var registreret som dansk. Appen blev pålagt bøder (»mulkter«) herfor. Papirerne befandt sig hos den preussiske konsul, der nu gik ind i sagen på Appens vegne. Sagen endte ved byens domstole, men var endnu ikke afgjort, da Bille rejste hjem.

\section{Steen Billes note til kineserne}

Snart viste det sig, at Bille var langt mere indstillet på at hjælpe de danske kaptajner, end Lemmermann havde anet, da de to mødtes ved Taku. Grunden til, at Bille ikke straks var gået ind i sagen, angiver han selv: "Jeg har alt ovenfor udtalt, at jeg med velberaadt Hu ikke vilde optræde personlig officielt lige overfor den chinesiske Regjering i denne Sag, og det hovedsagelig fordi jeg først og fremmest vilde have Ratificationerne udvexlet. Det var Hoved-Øiemedet for min Sendelse, og dets Opfyldelse maatte jeg sætte over alt Andet.« ${ }^{29}$ Da udvekslingen havde fundet sted, tog Bille bladet fra munden og sendte en note til det kinesiske udenrigsministerium (His Emperial Chinese Majestys Board of Foreign Affairs), et forsæt han allerede havde meddelt det danske udenrigsministerium dagen efter sin ankomst til Hongkong den 18. juni, da han var blevet opmærksom på opbringelserne.

Noten, dateret den 4 . august, indledte han med at takke for de kinesiske myndigheders beredvillighed ved udvekslingen af ratifikationerne og med meddelelsen om, at han nu var på vej hjem. Med det på plads kom han til sit egentlige ærinde: »It is well known, that Denmark at present is attacked by overwhelming enemies and that in consequence she is obliged to keep all her naval forces at home in defence of her territory «. Derfor kunne Danmark på nuværende tidspunkt ikke afse noget krigsskib til at beskytte sin blomstrende 


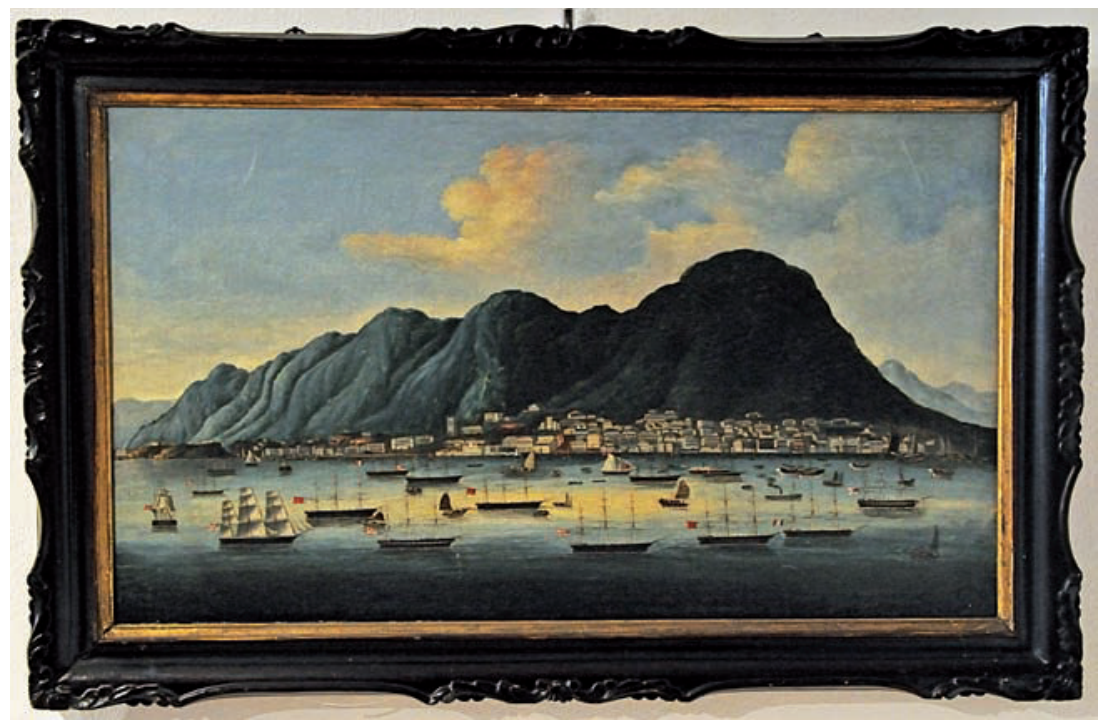

Kinesisk oliemaleri af den britiske koloni Hongkong fra anden halvdel af 1800-tallet. Hongkong havde nu udviklet sig til den vigtigste havneby på Kinakysten. Som det overvældende antal skibe fra mange forskellige nationer på reden indikerer, var Hongkong også i global sammenhæng en betydelig havneby. Dens status som britisk koloni betød, at der var et forholdsvis velorganiseret retsvæsen $i$ byen, som gjorde det attraktivt for vestlige handelshuse at etablere sig i byen. Foto: Museum Sønderjylland Kulturhistorie Tønder.

handel på Kinakysten. Danske handelsskibe ville således fortsat være i risiko for at blive opbragt af det preussiske krigsskib, som vist nok endnu befandt sig i området. Bille anså det som sin pligt at gøre den kinesiske regering opmærksom på, at den skulle tage slige forholdsregler, som påkrævet ifølge international ret og særligt i henhold til den dansk-kinesiske handelsaftales artikel 18. Forholdsreglerne skulle afværge overtrædelser af neutraliteten i de kinesiske farvande, således at danske priseskib ikke blev bragt ind i de kinesiske havne, og at preussiske orlogsskibe ikke blev tilladt at bruge kinesiske havne som forsyningsbaser for deres krigeriske aktiviteter. Bille påpegede, at således forholdt andre neutrale magter sig, og han henviste til et cirkulære udstedt af den britiske regering den 23. april, som forbød, at de krigsførende magter bragte priser ind i britiske havne. Cirkulæret var blevet bragt i Hongkong-avisen Government Gazette den 11. juni, utvivlsomt på foranledning af Gazelles opbringelser. Afslutningsvis opfordrede Bille den kinesiske regering til straks at instruere sine 
embedsmænd i de for europæiske skibe åbne havne om dette og om, at de skulle være de danske konsuler behjælpelige ved behov. ${ }^{30}$ Med denne meget direkte note afsluttede Bille sine diplomatiske aktiviteter i Kina, det var nu "... Consulens Sag i hvert enkelt Tilfælde ..., at træde op som Værge for de fraværende Skibs-Eieres Ret, mod det Overgreb der var skeet, ved uden forudgaaende lovmæssig Behandling at overføre deres Skib til en anden Besidder ... «. ${ }^{31}$

Nyheden om opbringelserne gik vidt omkring. I The South Australian Advertizer, onsdag den 13. juli, kunne man for eksempel læse følgende blandt nyhederne fra Kina og Japan:

»On the 26th ultimo the Prussian frigate Gazelle seized the Danish Schooner Falk outside Taku, and on the following day the Caroline, Danish Schooner, was also forced to hoist Prussian colours. The Catherine has since been seized, and a prize court was to have been assembled in Tientsin to adjudicate on the captures. There remain closely confined to the river above Taku, unable or unwilling to attempt an exit, Bessie Seawright, Therese Auguste and Dannebrog. Their movements will, for the present, depend on those of the Gazelle. The Prussian minister, Baron de Rehfues, has arrived at Peking, and has taken up his quarters at the French Legation. Trade continues dull, business appearing to pass, for the most part through the hands of the Chinese themselves. ${ }^{32}$

\section{Den preussiske gesandt hos prins Gong}

I midten af juli havde kineserne for længst taget affære. Gazelles opbringelser havde udløst en diplomatisk krise mellem Preussen og Kina, da nyheden om dem havde nået Peking. Guido von Rehfues ankom til Peking i slutningen af april, og få dage efter må nyhederne om opbringelserne være nået frem. Den mægtige prins Gong - svoger til den regerende kejserinde, Cixi, og leder af Zongli Yamen, det nyoprettede departement for udenrigske anliggender - reagerede ved ikke at gengælde von Rehfues henvendelser. ${ }^{33}$ Derved blev hans status som preussisk gesandt i Peking ikke anerkendt. Kinesernes reaktion blev begrundet med, at Gazelles aktiviteter i kinesisk territorialfarvand var en upassende måde for den preussiske diplomat at indlede sin embedstid på. Prins Gongs bekymringer lå deri, at lod kineserne opbringelserne passere, accepterede de samtidig preussernes præmis om, at aktionerne havde fundet sted i internationalt og ikke kinesisk 
farvand. Det ville åbne op for krav fra fremmede nationer, der ville indtage kinesiske områder. Derudover ønskede kineserne ikke en udvidelse af de europæiske stridigheder til Kina. Zongli Yamen blev nødt til at protestere. Departementet insisterede derfor på, at området var kinesisk farvand og henviste til den kinesisk-preussiske handelsaftale, hvori begrebet »kinesisk hav" blev anvendt om det område, hvor skibene var blevet opbragt. ${ }^{34}$

Prins Gong var en ambitiøs leder i færd med at styrke det udenrigspolitiske embedsapparat, så det kunne hamle op med vestlige diplomater. Et af prinsens aktuelle initiativer var en oversættelse af Henry Wheatons Elements of International Law (angiveligt obligatorisk læsning for vestlige diplomater) ved den amerikanske missionær W.A.P. Martin. Det første udkast var tilgået Zongli Yamen, og det blev nu diskuteret blandt de kinesiske ledere, om en udgivelse af værket på kinesisk skulle være næste skridt. Oversættelsen blev af stor betydning i forhandlingerne med preusserne, da prins Gong og hans stab i denne kunne hente de retlige argumenter, der var brug for mod vestlige magters krænkelse af kinesisk suverænitet.

Guido von Rehfues forsøgte forgæves at mobilisere de andre europæiske repræsentationer til at gøre fælles front, men han endte med at måtte forlade Peking i slutningen af juni. Han rejste dernæst hjem til Preussen for først at vende tilbage til Kina året efter. I slutningen af 1865 blev han anerkendt som preussisk gesandt efter at have forsikret, at skibene nu var frigivet. ${ }^{35}$

Da prins Gongs departement den 30. august 1864 sendte en skrivelse til regenten, var det for at gøre opmærksom på, hvor nyttig oversættelsen af Weatons værk allerede havde vist sig at være og det med henblik på at få tilladelse til en udgivelse:

»We, your ministers, find that this book of foreign laws do not entirely agree with our own laws, but there are in it occasional passages which are useful. For example, in connection with the case of Danish ships captured by Prussia outside of Tientsin, we used some sentences from the book without expressly saying so, as arguments. The Prussian ministers acknowledged his mistake without saying a word. This seems a good proof. «36

Departementet hævdede altså at have brugt sætninger fra det oversatte værk uden eksplicit at henvise til det, og den preussiske gesandt havde måttet acceptere argumentationen. Oversættelsen havde vist sit værd i legitimeringen af Tsungli Yamens fremgangsmåde. ${ }^{37}$ Regen- 


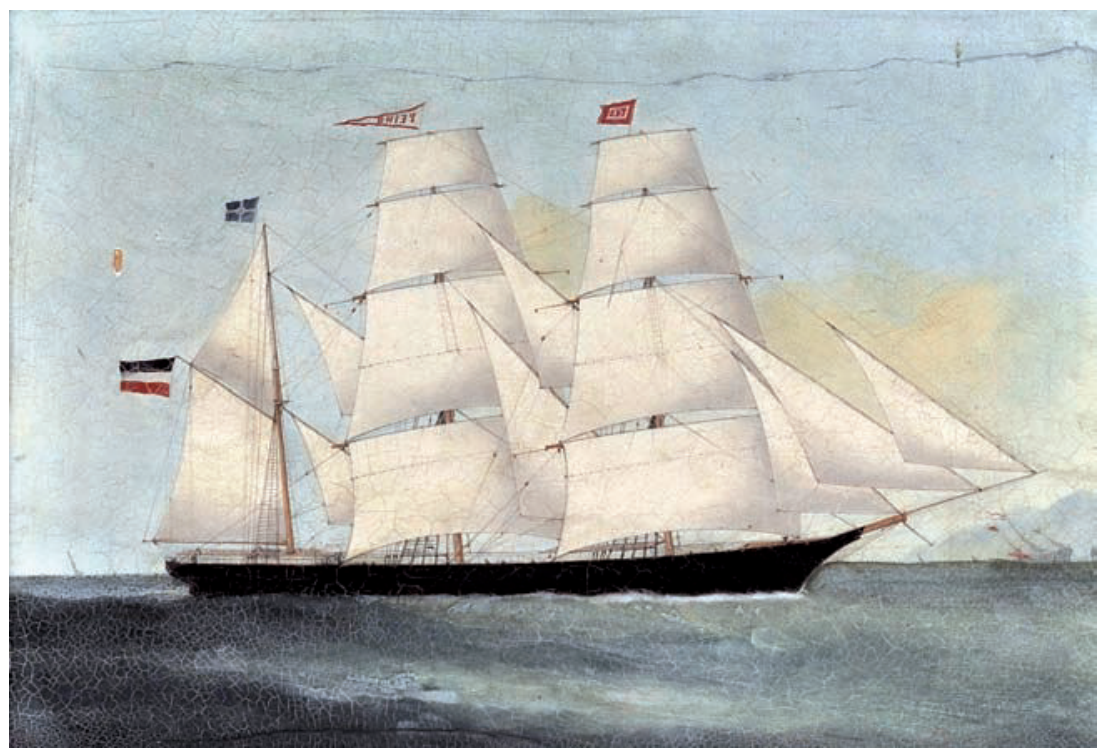

Der er ikke bevaret et skibsportræt af skonnertbriggen Falk, men på dette skibsportræt af barken Peiho, som også tilhørte Christian Karberg, kan rederiflaget ses vaje i mastens top. Peiho var bygget $i$ Sønderborg i 1864, hvorefter det straks gik til Østasien for aldrig siden at vende tilbage til Europa. I 1881 blev det solgt til et hollandsk rederi. Foto: Museum Sønderjylland - Kulturhistorie Aabenraa.

ten gav grønt lys for færdiggørelsen og udgivelsen af værket. Sagen blev en sejr for prins Gongs progressive linje over for mere konservative kræfter i den kinesiske regering, der mente, at man hverken kunne eller skulle forholde sig til det vestlige tankegods. Adskillige vestlige regler var allerede blevet Kina påtvunget $\mathrm{i}$ fredstraktaterne efter Opiumskrigene, og vestlig ret skulle ikke anerkendes som gældende i landet. Prins Gong hævdede herimod, at det var en fordel for kineserne at kende de internationale retsregler, som man kunne bruge til egen fordel, uden at man var nødsaget til at underkaste sig dem.

\section{Efterspil i Hongkong}

Den 24. august ankom Lemmermann til Hongkong, hvor han straks forelagde sagen om Falk for den danske konsul Georg Hellund. Dagen efter gik konsulen til den britiske viceadmiralitetsret, der omgående beslaglagde Falk. Nu gik det op for Lemmermann, at Alisch havde 


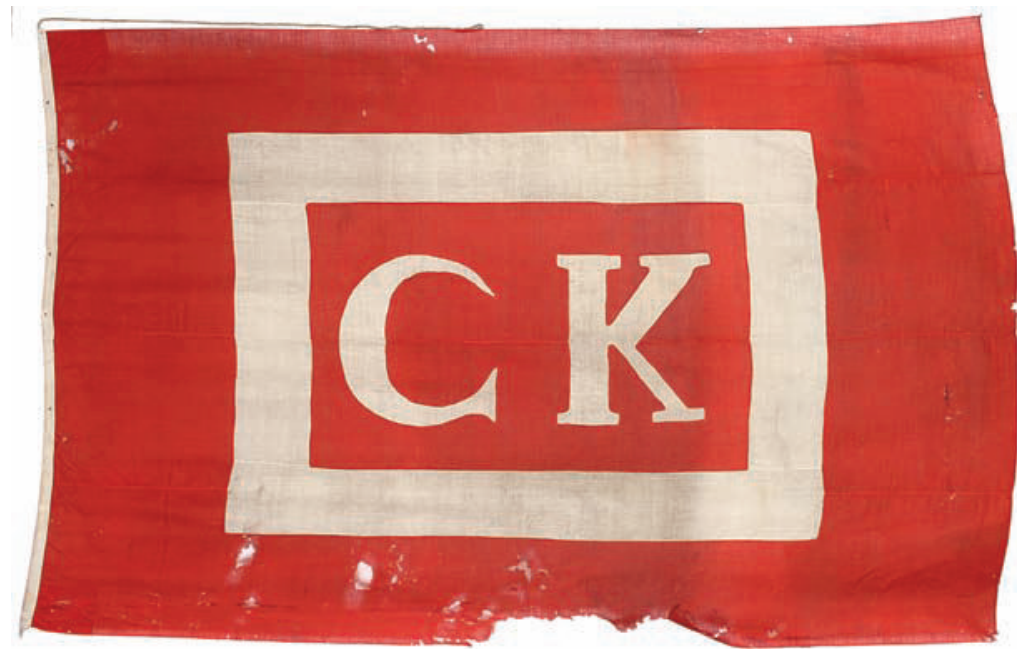

Karberg-rederiets $210 \times 310 \mathrm{~cm}$ store flag er det eneste bevarede sønderjyske rederiflag fra sejlskibstiden. Det må således have været sådan et flag, der vajede fra toppen af den ene af masterne på Falk. Foto: Museum Sønderjylland - Sønderborg Slot.

solgt Falk til sig selv til spotpris. Han mente dog ikke, at salget var gyldigt, da skibet ikke forinden havde været fremstillet for en prisedomstol. På et tidspunkt tilbød den preussiske regering Peter Karberg at betale Alischs' købspris på 1.500 mexicanske dollars i erstatning, men det blev afslået.

Den 27. august havde historien om Gazelles opbringelser nået Amerika. Daily Alta California informerede: »The Prussian frigate Gazelle has captured several Danish merchantmen, including the brig Catharina ${ }^{38}$

Først i slutningen af december 1864 skete der igen noget interessant i sagen. Alisch mødte op på den danske konsul Johannes Hellunds kontor i Hongkong. $\mathrm{Nu}$ ville han via sin agent $\mathrm{i}$ byen bringe sagen $\mathrm{i}$ orden - overdrage skibet og betale sagens omkostninger. Da Hellund kontaktede agenten den 27. december, havde denne imidlertid ingen instrukser fået, og Alisch, der var rejst, kunne ikke stilles til regnskab. Hjemme i Sønderborg skrev Christian Karberg samme dag et brev til G. Halkier og Co. i København. Firmaet skulle beregne hvor stort et tab, sagen havde påført ham, og foruden en skildring af sagen tilkendegav han, »du kan troe, at det er en uhyre vigtig Sag for mig, om jeg kan faa Skibet betalt tilligemed Fragten eller ikke«. 
Den 23. maj 1865 afsagde viceadmiralitetsretten i Hongkong dom i sagen. Christian Karberg blev kendt for skibets rette ejermand og skulle have udbetalt erstatning. I sommeren 1865 var Falk atter i fart på Kina-kysten. Den 28. juni udarbejdede Lemmermann et regnskab over sine udgifter. Ud over penge til et sendebud fra Tientsin til von Refues i Peking, til hvem kaptajnen ville anmelde sagen, var der primært tale om udgifter til rejser og overnatning. I Taku havde han således betalt sønderjyden H.P. Jertrum 18 \$ for kost og logi. Det tilsvarende beløb i Hongkong var 415,5 \$ for næsten et års ophold. Endelig havde Lemmermann betalt en "Surveyor « for at taksere og klassificere Falk den 15. juni 1865, altså efter han havde vundet sagen. Kaptajnen havde i alt lagt 658,5 \$ ud.

På trods af at Sønderborg-skibe, efter det danske nederlag i 1864krigen, skulle føre tysk flag, kunne den preussiske gesandt i Peking i april 1866 meddele, at Falk sejlede under dansk flag. ${ }^{39}$ Christian Karbergs nationale sindelag lod sig ikke fornægte, og samme år blev også Chin Chin omtalt som et dansk skib i både Singapore og Amoy. ${ }^{40} \mathrm{Med}$ tiden blev det klart for Christian Karberg, at han måtte kigge langt efter sin tilkendte erstatning, uanset at han både i 1866 og 1869 henvendte sig til myndighederne, noget der nok heller ikke gjorde ham venligere stemt over for Preussen. I 1870 blev den kritiske artikel i Dannevirke bragt og gjorde offentligheden opmærksom på problemet, men nogen reaktion fra de preussiske myndigheder kendes ikke.

\section{Ak, men hvor længe!}

Mens hertugdømmerne blev erobret derhjemme, blev nogle af de slesvigske og holstenske skibe således erobret af den preussiske Gazelle ude på Kinakysten. I alt fire danske skibe blev opbragt. Aktionerne var udramatiske, sammenlignet med krigshandlingerne derhjemme, men de var langt fra betydningsløse. Selvsagt skabte de utryghed om bord på danske skibe på Kinakysten, kaptajnerne blev opildnede, og de kinesiske befragtere så sig om efter skibe fra andre nationer. De ellers populære danske skibe tabte terræn til konkurrenterne. Stemningen blandt kaptajnerne endte med en fredelig indsamling til fordel for nødlidende i hjemlandet, og mindst tre muligvis alle fire opbragte skibe lykkedes det de danske konsuler at føre tilbage under dansk flag. Det var i den forbindelse, at Steen Bille resignerende bemærkede: »Ak, men hvor længe!« For preusserne førte opbringelserne til en di- 
plomatisk ydmygelse på grund af deres manglende respekt for kinesisk territorialfarvand og misbrug af kinesiske havne.

Anskuer man udløberen af krigen i 1864 på Kinakysten i et lidt større perspektiv, udstiller forløbet, hvor skrøbeligt det politiske grundlag for den danske handel og søfart i området var. Et enkelt preussisk krigsskib kunne gøre livet surt for samtlige danske skibe. Danmark havde ingen magtmidler på Kinakysten, kun skrøbelige handelsdiplomatiske forbindelser; man var afhængig af andre landes militær og retsvæsen. Der var ikke megen hjælp at hente hos de kinesiske myndigheder, som var blevet tvunget til at acceptere de europæiske skibes sejlads på landets havnebyer gennem de to Opiumskrige. Det var således de vestlige stormagters militære tilstedeværelse og vilje til at anvende krigsmagt, der sikrede danske skibe adgang til handel på Kinakysten.

Langt vigtigst i den vestlige tilstedeværelse på Kinakysten var briterne, og derfor kunne kaptajn Ohlsen på Peiho konkludere, at hvis briterne gik ind i krigen på dansk side »dann bin ich unter Dänische Flagge auf der rechten Seite«. Det gjorde briterne som bekendt ikke, og Danmark tabte krigen 1864. Nu måtte alle de slesvigske og holstenske skibe skifte det danske flag ud med det preussiske - selvom nogle ulydigt fortsatte under dansk flag i et par år. Situationen blev dog ikke forandret væsentligt. Preussen var ikke nogen stærk sømagt, og under krigen mod Frankrig i 1870-71 blev mange tyske skibe lagt op i fjernøstlige farvande. Blandt Christian Karbergs omtalte skibe måtte såvel de to skonnerter Falk og Activ som barken Java oplægges. Denne gang fik rederen dog erstatning for tabt fortjeneste for alle sine oplagte skibe, hvilket han, efter det bevarede materiale at dømme, aldrig fik for opbringelsen af Falk i 1864.

\section{KILDER OG LITTERATUR}

Utrykte kilder:

Landsarkivet for Sønderjylland:

Kaptajn Jes Peter Boysens kopibøger, Søfartssamlingen, pk. 1.

Kaptajn Ohlsons breve, Hans Schlaikiers privatarkiv.

Sønderborg Slot:

Sønderborg Skipperlaugs arkiv, enkelte skibe og deres rejser, 1864-1865
Skonnerten "Falk «, Sønderborg, taget 1864 som prise af den prøjsiske korvet »Gazelle« i kinesisk farvand: Akter fra sag ved engelsk viceadmiralitetsret i Hong Kong., pk. nr. E 27.

Rigsarkivet:

Shanghai, konsulær repræsentation, 1842-1904, Korrespondancesager mv. 1864, pk. 70. 
Bille, Steen Andersen, admiral, 1864, Sager vedr. S. Billes gesandtskabsrejse til Kina, pk. 11.

\section{Hjemmesider:}

Trowe: Digitized newspapers and more: http:/ / trove.nla.gov.au/ndp/ $\mathrm{del} /$ article/31838915

\section{Litteratur og trykte kilder:}

Bille, Steen (Viceadmiral): Min Reise til China i 1864. København 1865.

Dybbøl-Posten den 29. april 1896.

Holm-Petersen, F.: Under sejl i fjernøstlige farvande. Norderstedt 1975.

Hsü, C.Y. Immanuel: China's entrance into the family of nations. The diplomatic phase. Cambridge (Massachusetts) 1960.

Jespersen, Mikkel Leth: »Om den duelige kaptajn og skibets interesse. Et kærlighedsdrama fra Aabenraa-søfartens storhedstid «, Sønderjyske Arbøger 2013, s. 89-115.

Knudsen, Niels: Sønderborg Skipperlaug 1571-1971. Sønderborg 1971.

Liu, H. Lydia: The Clash of Empires. The Invention of China in Modern World Making. Cambridge 2004.

Mensing, Adolf: An Bord der GAZELLE nach Yokohama. Ein preußischer Marineoffizier erinnert sich. Horst Auerbach (red.), Rostock 2000.

Nielsen, Erik Møller: Fra Klamp til Konstruktion. Fra håndwark til ingeniørkunst $i$ Aabenraa's sejlskibsbyggeri ca. 1800-1880. Aabenraa 2000.

Radowitz, Joseph Maria von: Aufzeich- nungen und Erinnerungen aus dem Leben des Botschafters Joseph Maria von Radowitz, Hajo Holborn (udg.), bd. 1: 1839-1877, bd. 2: 1878-1890, Stuttgart 1925.

Schiffahrt und Häfen im Bereich der Industrie- und Handelskammer zu Flensburg, Hans-Friedrich Schütt (red.). Flensborg 1971.

Skougaard, Mette og Thomas Lyngby: »Kinesisk besøg. Et kejserligt palads udstillet på Frederiksborg ", Carlsbergfondets Årsskrift 2013, s. 148-155.

Stoecker, Helmuth: Deutschland und China im 19. Jahrhundert. Das Eindringen des deutschen Kapitalismus. Berlin 1958.

Sønderborg bys historie, bd. 1 og 2. Holger Hjelholdt (red.), Sønderborg 1960 og 1966.

Sønderjyllands Historie. Efter 1815, bd. 2. Hans Schultz Hansen m.fl. (red.), Aabenraa 2009.

Tsiang, T.F.: »1. Origins of the Tsungli Yamen« og »2. Bismarck and the Introduction of International Law into China «, The Chinese Social and Political Science Association, hæfte 15, 1931, s. 92-101.

Verzeichniss der Schleswig-Holsteinischen Rhederei ult. 1864. Nach officiellen Quellen zusammengestelltes Verzeichniss aller in Schleswig-Holstein zu Hause gehörenden Schiffe von 10 Lasten und darüber, in alphabetischer Reihenfolge und districtsweise geordnet. Kiel 1865.

\section{NOTER}

1. Rigsarkivet, Shanghai, konsulær repræsentation, 1842-1904, Korrespondancesager mv. 1864, pk. 70; Rigsarkivet, Bille, Steen Andersen, admiral, 1864-1864, Sager vedr. S. Billes gesandtskabsrejse til Kina, pk. 11.

2. Dannevirke 29.4.1870.

3. Sønderborg Slot, Sønderborg Skipperlaugs arkiv, enkelte skibe og deres rejser, 1864-1865 Skonnerten »Falk «, Sønderborg, taget 1864 som prise af den prøjsiske korvet »Gazelle« i kinesisk farvand: Akter fra sag

ved engelsk viceadmiralitetsret i Hong Kong, pk. nr. E 27.

4. Jespersen, Mikkel Leth (2013), s. 96.

5. Jes Peter Boysens kopibøger 7.1. 1864.

6. Sønderjyllands Historie bd. 2, s. $122 \mathrm{ff}$.

7. Kaptajn Lemmermanns brev til Christian Karberg den 20. juni, Sønderborg Slot, Skipperlaugets arkiv.

8. Jes Peter Boysens kopibøger 28.8. 1864.

9. Sønderborg bys historie, Holger Hjelholdt (red.) Sønderborg 1960 og 
1966 , bd. 1, s. $242,270,301$, bd. 2 s. $88,93$.

10. Bragt i Dybbøl-Posten 29.4.1896, da Christian Karberg døde 91 år gammel som byens ældste borger,

11. Sønderborg Slot, Sønderborg Skipperlaugs arkiv, enkelte skibe og deres rejser, 1864-1865 Skonnerten »Falk «, Sønderborg, taget 1864 som prise af den prøjsiske korvet »Gazelle« i kinesisk farvand: Akter fra sag ved engelsk viceadmiralitetsret $i$ Hong Kong.

12. Nielsen, Erik Møller (2000), s. 158.

13. Om Falks sejlruter se blandt andet Holm-Petersen s. 129.

14. Radowitz bd. 1., s. 63.

15. Bille, Steen (1865), s. 198.

16. Rigsarkivet, Shanghai, konsulær repræsentation, 1842-1904, Korrespondancesager mv. 1864, pk. 70.

17. Rigsarkivet, Shanghai, konsulær repræsentation, 1842-1904, Korrespondancesager mv. 1864, pk. 70.

18. Bille, Steen (1865), s. 148f.

19. Bille, Steen (1865), s. 201f.

20. Bille, Steen (1865), s. 185.

21. Sønderborg Slot, Sønderborg Skipperlaugs arkiv, enkelte skibe og deres rejser, 1864-1865 Skonnerten »Falk«, Sønderborg, taget 1864 som prise af den prøjsiske korvet »Gazelle« i kinesisk farvand: Akter fra sag ved engelsk viceadmiralitetsret $i$ Hong Kong.

22. Bille, Steen (1865), s. $40 f$.

23. Landsarkivet for Sønderjylland, Hans Schaikiers Privatarkiv. Skibets navn nævnes ikke i brevene, men det kan identificeres ud fra Verzeichniss der Schleswig-Holsteinischen Rhederei ult. 1864, s. 23.

24. Cirkulæret omtales i Steen Billes rejsebeskrivelse fra 1865, s. 195.

25. Rigsarkivet, Shanghai, konsulær repræsentation, 1842-1904, Korrespondancesager mv. 1864, pk. 70.

26. Rigsarkivet, Bille, Steen Andersen, admiral, 1864, Sager vedr. S. Billes gesandtskabsrejse til Kina, pk. 11.

27. Bille, Steen (1865), s. 197.

28. Bille, Steen (1865), s. 198.

29. Bille, Steen (1865), s. 199.

30. Rigsarkivet, Shanghai, konsulær repræsentation, 1842-1904, Korrespondancesager mv. 1864, pk. 70.

31. Bille, Steen (1865), s. 201.

32. http://trove.nla.gov.au/ndp/del/ article/3183891. Samme tekst blev bragt i China Mail den 2. juni. Her fremgår det, at den var hentet i North China Herald og Japan Market Report. Disse oplysninger er venligst meddelt af Rhonda Staskow, som forsker i skibe, bygget på Reimers værft i Aabenraa.

33. Skougaard, Mette og Thomas Lyngby (2013), s. $149 f$.

34. Hsü, C.Y. Immanuel (1960), $132 \mathrm{ff}$.

35. Stoecker, Helmuth (1958), s. 63.

36. Tsiang, T.F. (1931), s. 99 f.

37. Liu, H. Lydia (2004), s. $120 \mathrm{ff}$.

38. Daily Alta California, Volume 16, Number 5290, 27.8.1864, http: / / cdnc.ucr.edu/cgi-bin/ cdnc? $\mathrm{a}=\mathrm{d} \& \mathrm{~d}=\mathrm{DAC} 18640827.2 .7 \#$

39. Holm-Petersen, F. (1975), s. $129 f$.

40. Holm-Petersen, F. (1975), s. 125.

\section{Zusammenfassung}

1864 hatte die Seefahrt der Herzogtümer auf China einen erheblichen Umfang erreicht und war auf dem Gebiet der dänischen Wirtschaftsinteressen im Fernosten dominierend. Die schleswigschen Handelsschiffe hatten in Apenrade, Sonderburg und Flensburg ihre Heimathäfen, die holsteinischen Schiffe kamen fast alle aus Altona. Bei Kriegsausbruch 1864 stellte sich heraus, dass die Position der Chinafahrer aus den Herzogtümern unsicher war. Preußen hatte vor Kriegsausbruch die Kriegskorvette Gazelle in den Fernosten auf diplomatische 
Mission geschickt und konnte sie jetzt gegen den dänischen Handel an der Chinaküste einsetzen. Die Handelsschiffe konnten gegen ein modernes dampfgetriebenes Kriegsschiff nichts aufstellen. Obwohl es durch die Gazelle nur zum Aufbringen von vier Schiffen kam, verbreitete sich an Bord der anderen dänischen Schiffe eine Unsicherheit. Gleichzeitig führte dies zu langen diplomatischen Verwicklungen. 